\title{
The Effect of Organizational Culture and Manufacturing Strategy on Firm Performance through Business Process Re-engineering
}

\author{
Hotlan Siagian*, Hatane Semuel, William Gondo Widjaja \\ Petra Christian University, Jl. Siwalankerto 120-131, Surabaya, Indonesia. \\ * Corresponding author. Tel.: +62312983256; email: hotlan.siagian@petra.ac.id \\ Manuscript submitted January 12, 2017; accepted June 5, 2017. \\ doi: 10.17706/ijeeee.2017.7.3.191-201
}

\begin{abstract}
Many studies have focused on the direct impact of organizational culture, business process re-engineering, manufacturing strategy on the firm performance. This study examined the impact of organizational culture and manufacturing strategy on organization performance through business process re-engineering. Data were collected using questionnaires distributed to 111 respondents representing 37 cosmetics manufacturing firms located in the region of East Java, Indonesia. Statistical analysis was performed using partial least square (PLS) software. The result concluded that there was a direct influence on organizational culture, manufacturing strategy on firm performance. The mediating role of business process re-engineering on firm performance exists and significant. Manufacturing strategy gives greater impact on firm performance than organizational culture does.
\end{abstract}

Key words: Business process re-engineering, firm performance, manufacturing strategy, organizational culture.

\section{Introduction}

Recently, a considerable literature has grown up around the theme of how to improve an organization performance in anticipating the global competition. In the context of supply chain management, many researches have been conducted to study how to define and improve an organization performance. Several researchers [1]-[4] have defined the performance of an organization and however, those studies did not define the performance in the same manner. Nevertheless, those definitions have the dimension of performance in commons such as financial performance, operational performance, customer satisfaction and employee satisfaction. Reference [2] defined the performance being composed of five dimensions i.e. quality, delivery time, cost, customer satisfaction and employee satisfaction. The question raised is how to enhance this performance. Reference [5] argued that that performance can be improved through business process re-engineering (BPR) however business process re-engineering is not a stand-alone concept. It has an antecedent variable which supports its successful implementation. Other research by [6] explained that organizational culture supports the successful implementation of business process re-engineering which means that the successful implementation of the business process re-engineering should be aligned with the prevailing culture of the organization. Beside organizational culture [7] explained that the manufacturing strategy also has a significant relationship to the implementation of business process re-engineering that subsequently has an impact on firm performance. That means that business process 
re-engineering should be in line with the manufacturing strategy.

It can be summarized that most of the studies have extensively focused on the direct impact of business process re-engineering, organizational culture, and manufacturing strategy on the organization performance. However, very few focused on the indirect impact through mediating role of the business process re-engineering. As understood, business process re-engineering is a way to align the strategy with the business process.

The present study emphasizes on the examination of the mediating role of the business process re-engineering in influencing firm performance with manufacturing strategy and organizational culture as independent variables. This study, therefore, addresses three research questions. First, how firmly the organizational culture and manufacturing strategy influence organization performance through mediating role of business process re-engineering. Second, how strong business process re-engineering affects the performance directly and third, how strongly organizational culture and manufacturing strategy directly influence firm performance.

The remainder of this paper is divided into five sections. The first section reviews the relevant theory on the four concepts being examined including the relationship of the ideas based on the research questions discussed previously. The second details the relationship of the ideas suggested above and proposes the research hypotheses. The third presents the sample, measures, and analytical techniques. The fourth sections discussed the result of the study based on the data obtained and the result of the structured model. Finally, the last section discussed the conclusions and implication of the research and proposed the future research direction.

\section{Review of Literature}

\subsection{Firm Performance}

Performance is defined as the degree to which the company goals and objectives have been achieved. Performance is the result of work which is concrete, observable and measurable. It is the result of operational activities in utilizing its resources for a particular period. Reference [4] proposed balanced scorecard as a measure of firm performance in term of financial, customer satisfaction, internal process and organizational ability to learn. Financial measurement determines the past financial achievement within a particular period of time such as return on sale or return on investment. Meanwhile, customer satisfaction measures the extent to which the firm fulfill its customer's expectation. The next term is the internal process which measures the achievement of the internal process in term of time, quality and cost. The last measure is the ability of the organization to learn which is imperative for the organization to remain to exist in the market. Other researcher defined that the company performance could be measured using market share, sales growth and profit [2]. This market share indicated the magnitude of its contribution, in percentage, compared to overall market served by all competing firms. The second term is the sales growth, to measure the degree to which the company grows in sales. The company with positive sales growth indicates that the firm has broadened their market which also the indication of a successful strategy. Meanwhile, profitability also indicates if the enterprise makes a positive or negative margin from its business activities. Another definition of the company performance was also used by other researcher using cost, quality, delivery time, customer satisfaction and employee satisfaction as a measure of firm performance [7]. Here, the cost is defined as the overall cost incurred in producing any product. This cost determines the competitive advantage of the product in term of price. While quality is a measure of how far the firm fulfills customer expectation in respect of product specification. Customer satisfaction measures the extent to which company has provided the product or services following customer need. This customer satisfaction not only determined by a product quality itself but also by other aspects such as after sales 
service, customer complaint handling, etc. The firm will be able to achieve its goal if the employee works hard and give their best effort in their work as an individual employee or as a member of a team work respectively. The employees provide their best effort once they are satisfied with their work environment. Hence, employee satisfaction achievement is one of the firm performance indicators. Reference [3] have developed a subjective measurement of the company performance composed of four items: sales volumes, profitability, market share and customer satisfaction. Taken together from those four works, it is found that there are similarities and also differences among the arguments. Nevertheless, in common, they measured the firm performance through three aspects covering financial, customer satisfaction and employee satisfaction. Based on this discussion, this study company performance is measured using the four indicators, i.e., profitability, market share, customer satisfaction and employee satisfaction which were assessed using subjective approaches. The reason to use this firm performance measure is its relevance with the culture of the company and the respondent ability to complete the questionnaires in the area of survey i.e. Surabaya, Sidoarjo, and Mojokerto, East Java of Indonesia.

\subsection{Business Process Re-engineering (BPR)}

Business process re-engineering is the fundamental rethinking and redesign of business processes to obtain dramatic improvements in cost, quality, service and speed [8]. Reference [9] stated that the BPR is a business process management tool which reviewed and redesigned the process to improve cost efficiency and effectiveness of services. BPR makes changes to the organization or human resources, processes and technology. BPR emerged as an enterprise solution to improve company performance in term of effectiveness, efficiency and shaping competitive advantage in a constantly changing globalized world [10]. Reference [7] has developed the dimensions as a measure of BPR composed of: the need for organizational change, the value of BPR implementation, the presence of open communication, the existence of confidence and trust, the creature of a cooperative environment, providing appropriate training and the effect of BPR on performance. All of the above works of literature described the importance of implementing the business process re-engineering in the course of superior performance. On this study, the measure of business process re-engineering used that one proposed by [7].

\subsection{Organizational Culture}

Organizational culture is defined as the dominant values disseminated within the organization and referred to as the philosophy of the employee. Organizational culture as the guiding value in the face of external problems so that member organizations must understand those values and know how they should act or behave [6]. The indicator used to measure organizational culture as follows: innovation, focus on details, the orientation of human resources, the direction of teamwork and performance stability. Reference [11] argued that organizational culture and religion plays a vital role in shaping and controlling employee behavior and perception regarding corruption. This paper examined the relationships between organizational culture, religious and corruption in public organization setting. Reference [12] found that training and leading by example can serve as effective methodologies for promoting culture awareness and bringing about culture change in organizations. Reference [13] stated that there is a significant influence of organizational culture toward organization performances, the effect of organization performances toward employee satisfaction, the influence of organizational culture toward customer satisfaction, and direct impact on organizational culture, based on organization performance, toward employee satisfaction.

\subsection{Manufacturing Strategy}

Manufacturing strategy can be regarded as a competence of a firm to enhance its performance. Some studies suggest that manufacturing strategy contributed to the company's business competitiveness. 
Manufacturing strategy should be such in-line with the company's competitive strategy that the objective can be achieved with the right strategy. There are two kinds of the company's competitive strategy: cost leadership and differentiation. Competitive strategy of the enterprise affects the manufacturing strategy, especially in making decisions about operational aspects. The manufacturing strategy mediates the relationship between competitive strategy and firm performance [14]. On this study, four dimensions were used to measure manufacturing strategy, i.e., quality, delivery, cost, and flexibility [15]-[17].

\section{Hypothesis}

\subsection{Organizational Culture and Business Process Re-engineering Relationship}

The organizational culture could affect the success of business process re-engineering. This is reasonable because the business process re-engineering is implemented by the firm's employee together with the management team. They naturally have their organizational culture formed during their extended period interaction within an organization. Each organization has their specific culture in nature which could be different compared with other firm has. The question is whether the current culture tailored with the business process re-engineering needed. Hence, the way the business process re-engineering implemented is logically related to the organizational culture. Reference [6] argue that organizational culture could affect the successful implementation of business process re-engineering. Hence, it is appropriate to empirically investigate the relationship between organizational culture and business process re-engineering on this study. This leads to the first hypothesis:

Hypotheses 1. Organizational culture influences business process re-engineering

\subsection{Organizational Culture and Firm Performance Relationship}

Organizational culture represents how the employee of an organization act and behave [6]. This culture should be, in nature, corresponds to the organization value to be achieved. It could be implied that culture is related to productivity and affects the firm performance directly. Reference [18] suggested that culture of a corporation powerfully influences its economic performance, for better or for worse. In other word culture of a company could either enhance firm performance or lead to failure. An organizational culture which fits firm's current strategy will not sustain over long periods unless they adopt strategies and practices that continuously respond to changing markets and new competitive environments. Hence, this concludes that culture of an organization influence the firm performance in the sense of better or worse which depends on the ability of the corporation to adapt the constantly changing environment. References [19] suggest that in the current economic climate, every organization must adopt a culture ability to cope with radical changes to satisfy the customer demands which in return leads to superior performance. Otherwise, it will result in inferior performance. Hence, it is reasonable to assume that organizational culture influence firm performance. This leads to secondary hypotheses:

Hypotheses 2. Organizational culture influences firm performance

\subsection{Manufacturing Strategy and Business Process Re-engineering Relationship}

Reference [7] explained that the manufacturing strategy has a significant relationship to the implementation of business process re-engineering that subsequently has an impact on firm performance. This means that business process re-engineering should be aligned with the manufacturing strategy. Manufacturing strategy must be owned by companies to pursue the growth and to compete in global business. Manufacturing strategy should be in line with the company's competitive strategy so that the objective can be achieved with the right business process [14]. Manufacturing strategy and competitive strategy has a positive and significant correlation between the performance of companies in Ghana. Manufacturing strategies are used in line with the competitive strategy of the company either cost 
leadership or differentiation strategy. The results of the study conducted by [7] confirmed the need for a strategy-driven BPR approach and the positive impact of BPR on performance. This confirms empirically that manufacturing strategy affects business process re-engineering and it further gives an impact on the firm performance. Therefore, the following third hypotheses are proposed:

Hypothesis 3. Manufacturing strategy influence business process re-engineering

\subsection{Manufacturing Strategy and Firm Performance Relationship}

Research conducted by [2] confirms that manufacturing strategy and competitive strategy have an impact on firm performance among Ghanaian manufacturing companies. There is a relationship between competitive strategy and the manufacturing strategies of cost, delivery, flexibility, and quality. Hence, the firm in pursuit of improving performance could focus on the manufacturing strategy achievement. Research by [20] indicated the influence of alignment between manufacturing strategy and business strategy on business performance and the contribution of manufacturing performance to business performance. The finding from this research proves that the alignment of manufacturing strategy and business strategy positively influences business performances. Fourth hypotheses are stated formally:

Hypotheses 4. Manufacturing strategy influences firm performance

\subsection{Business Process Re-engineering and Firm Performance Relationship}

Re-engineering can separate the company from the old functions through the reorganization, the elimination of several processes that are ineffective or find the most practical method. Business Process Re-engineering is widely used as a management tool for the organization Estonia because the BPR has a significant positive effect on firm performance[21]. Re-engineering conducted on locomotive operations management processes at Railways of Iran (RAI), the distribution process is the most critical processes, increase productivity and profits for the company[22]. Reference [23] agree that the implementation of the business process re-engineering improve the performance of the enterprise and enable to maintain the viability of the business. Reference [24] has been practicing BPR on Air Conditioning Company under General Electric Ltd. and prove that efficiency improvement followed by a decreased in processing time significantly. In general, the approach undertaken through BPR has a positive influence on business performance. Hence, the fifth hypotheses are as followed:

Hypotheses 5. Business process re-engineering (BPR) influence firm performance

\section{Methodology}

\subsection{Sample and Data Collection}

The population of this study is 37 cosmetic manufacturing firms which are located in the region of East Java, Indonesia i.e. in the City of Surabaya, Sidoarjo, and Mojokerto. All of these companies participated in the survey. Each company was represented by three respondents from top management levels, such as CEO, General Manager and other highest ranking official as they are considered the person most knowledgeable of the firm particularly in respect of related variables being studied. Questionnaires were distributed to 111 respondents representing 37 cosmetic companies. The reason to involve three (3) respondents from each company is to eliminate the bias due to personal subjectivities. Thus, the average assessment value of the three respondents represents each company. To make sure the information obtained is correct, an interview and discussion were conducted with the several respondents when considered necessary. The questionnaire is designed using subjective multi-item indices to measure each manifested variables or indicator using a five-point Likert-type scale Those items were measured using the five-point Likert scale from $1=$ strongly disagree up to $5=$ strongly agree. Research type in this study is a causal research with the objective to examine the relationships between variables. 
From the total of 37 firms, 33 have correctly completed the questionnaires representing the response rate of $89.1 \%$. The obtained data were then analyzed using Partial least square (PLS) software to assess the measurement model and structural model for the hypotheses testing. PLS is an appropriate tool for analyzing the data particularly in the case small sample size [25], [26] and limited theoretical knowledge [27]. PLS offers a predictive capability in the event of limited literature reference such as in this study and also appropriate for multi-scales measurement.

\subsection{Operational Definition of Variables}

It has been noted in the earlier discussion, firm performance was assessed using four measures i.e. profitability, sales growth, customer satisfaction and employee satisfaction based on the modified work of [7] and [3]. The profitability and sales growth were measured with one subjective item each that asked the respondent if the firm achieved the firm annual target. Customer and employee satisfaction was also measured using one subjective item each that asked the respondent whether their customer and employee were satisfied. Business process re-engineering (BPR) was assessed with referring to the concept proposed by [7] that asked the respondent if 1) the firm needs organizational change, 2) there is value of BPR implementation, 3) management applied open communication, 4) there is confidence and trust between management and employee, 5) there is cooperative environment within organization, 6) management performs timely training and 7) business process re-engineering give positive effect on performance. While organizational culture was assessed based on the work of [6] that asked the respondent if the firm is innovation oriented, focus on details, human resources oriented, teamwork oriented and stable company performance. The last variable, manufacturing strategy was measured with subjective four items that asked the respondent if the firm achieved annual target of quality, delivery/shipping, cost and flexibility [15]-[17]. Those items were measured using the five-point Likert scale from $1=$ strongly disagree up to $5=$ strongly agree.

\section{Result and Analysis}

The first analysis is to assess the measurement model (outer model) by evaluating the convergent and discriminant validity of each indicator and the reliability of the block indicators of each variable. The next step is to examine the structural model (inner model) through the assessment of the patch coefficient together with its $p$-value or $t$-value.

Table 1. Indicator Factor Loading

\begin{tabular}{|c|c|c|c|c|c|}
\hline Item & $\begin{array}{l}\text { Factor } \\
\text { loading }\end{array}$ & Item & $\begin{array}{l}\text { Factor } \\
\text { loading }\end{array}$ & Item & $\begin{array}{c}\text { Factor } \\
\text { loading }\end{array}$ \\
\hline \multirow{2}{*}{$\begin{array}{l}\text { Innovation (X11) } \\
\text { Detail focus (X12) }\end{array}$} & 0,606 & Cost (X23) & 0,662 & Timely training (M6) & 0,659 \\
\hline & 0,732 & Flexibility (X24) & 0,601 & $\begin{array}{l}\text { Effect on performance } \\
\text { (M7) }\end{array}$ & 0,710 \\
\hline $\begin{array}{l}\text { Human resources } \\
\text { orientation (X13) }\end{array}$ & 0,680 & $\begin{array}{l}\text { Need of organizational } \\
\text { change (M1) }\end{array}$ & 0,604 & Profitability (Y1) & 0,629 \\
\hline $\begin{array}{l}\text { Teamwork } \\
\text { orientation(X14) }\end{array}$ & 0,638 & $\begin{array}{l}\text { Value of BPR } \\
\text { implementation (M2) }\end{array}$ & 0,651 & Sales growth (Y2) & 0,701 \\
\hline $\begin{array}{l}\text { Performance } \\
\text { stability }(\mathrm{X} 15)\end{array}$ & 0,712 & $\begin{array}{l}\text { Open communication } \\
\text { (M3) }\end{array}$ & 0,780 & $\begin{array}{l}\text { Customer } \\
\text { satisfaction(Y3) }\end{array}$ & 0,721 \\
\hline Quality (X21) & 0,687 & $\begin{array}{l}\text { Confidence \& trust } \\
\text { (M4) }\end{array}$ & 0,833 & $\begin{array}{l}\text { Employee satisfaction } \\
\text { (Y4) }\end{array}$ & 0,670 \\
\hline Delivery (X22) & 0,650 & $\begin{array}{l}\text { Cooperative } \\
\text { environment (M5) }\end{array}$ & 0,736 & & \\
\hline
\end{tabular}

Table 1 lists the factor loading of each indicator. All factor loading of the indicators exceed the recommended minimum of 0.50 [28] in all cases (range 0.601 to 0.833). Hence, all indicators are considered valid. Table 2 lists the value of Average Variance Extracted (AVE) and Composite reliability (CR). The composite reliability exceeded the recommended minimum value of 0.70 in all cases (range 0.882 to 
0.919) [29]. The value of AVE exceeded accepted minimum value of 0.50 in all cases (range 0.601 to 0.676 ). This magnitude of AVE demonstrated that measurement model has an acceptable validity and reliability in all cases.

Table 2. AVE and Composite Reliability

\begin{tabular}{lcc}
\hline \multicolumn{1}{c}{ Variable } & AVE & CR \\
\hline Organizational culture (X1) & 0,601 & 0,882 \\
Manufacturing strategy (X2) & 0,684 & 0,896 \\
$\begin{array}{l}\text { Business Process Re-engineering } \\
\text { (M) }\end{array}$ & 0,623 & 0,919 \\
Firm Performance (Y) & 0,676 & 0,912 \\
\hline
\end{tabular}

As noted, PLS is a non-parametric estimation procedure. Hence, bootstrapping method was used to extract $t$-value to ascertain the significance level of each path coefficient to examine the hypotheses. Inner model assessment using PLS does not directly calculate the goodness of fitness. The primary method used to assess the inner model is by examining the variance explained called $\mathrm{R}^{2}$. Table 3 lists the variance explained $\left(R^{2}\right)$ for each dependent variable i.e. business process re-engineering (BPR) and firm performance. This value of $\mathrm{R}^{2}$ are comparable to values typically reported in performance research ([30].

Table 3. Variance Explained (R²)

\begin{tabular}{ll}
\hline Variable & Variance Explained $\left(\mathrm{R}^{2}\right)$ \\
\hline Organizational culture & - \\
Manufacturing strategy & - \\
Business Process Re-engineering (BPR) & 0,851 \\
Firm Performance & 0,889 \\
\hline
\end{tabular}

Other measurement used to assess inner model is its predictive relevance which is denoted as $\mathrm{Q}^{2}=1$ $\left(1-R_{1}{ }^{2}\right)\left(1-R_{2}{ }^{2}\right)$. This value depends on the value of $R^{2}$ of each endogenous construct. The value of $Q^{2}$ ranging from 0.00 to 1.00 . As the value approach to 1.00 , the better is the power of the inner model. The result of $\mathrm{Q}^{2}$ is 0.942 which means the independent variables have a good performance in predicting dependent variables.

Those hypotheses were examined with referring to the value of the path coefficient and $t$-value or $p$-value obtained from PLS result. Table 4 lists the path coefficient $(\beta)$ and $t$-value for each relationship.

Table 4. Path Coefficient and T Statistic

\begin{tabular}{lcccc}
\hline \multicolumn{1}{c}{ Path coefficient } & $\begin{array}{c}\text { Original } \\
\text { Estimate }(\beta)\end{array}$ & $\begin{array}{c}\text { Mean of } \\
\text { subsamples }\end{array}$ & $\begin{array}{c}\text { Standard } \\
\text { deviation }\end{array}$ & T statistic \\
\hline Org. Culture $\rightarrow$ BPR $^{1}(\mathrm{H} 1)$ & 0,407 & 0,422 & 0,100 & 4,081 \\
Org. Culture $\rightarrow$ Firm Performance (H2) & 0,165 & 0,164 & 0,081 & 2,046 \\
Manuf. Strategy $\rightarrow$ BPR (H3) & 0,567 & 0,554 & 0,097 & 5,877 \\
Manuf. Strategy $\rightarrow$ Firm Performance & 0,276 & 0,284 & 0,116 & 2,370 \\
$(\mathrm{H} 4)$ & & & & \\
BPR $\rightarrow \quad$ Firm Performance (H5) & 0,543 & 0,536 & 0,161 & 3,375 \\
\hline \multicolumn{1}{l}{ BPR: Business process re-engineering } & & & &
\end{tabular}

Based on the significance level of $5 \%$ or $t$-value of 1.96, the results demonstrated that all path coefficients are positive and significant. As expected Organizational culture $(\beta=0.407$ and $t$-value $>1,96)$ and Manufacturing strategy $(\beta=0.567$ and $t$-value $>1,96)$ have impact on business process re-engineering. This result confirms the previous research on the organizational culture and manufacturing strategy have an impact on the business process re-engineering. This finding supported hypotheses $\mathrm{H} 1$ and H2. Furthermore, organizational culture has a direct impact on firm performance $(\beta=0.165$ and $t$-value $>1.96)$, and similarly, manufacturing strategy has a direct impact on business process re-engineering $\beta=0.276$ and $\mathrm{t}$-value $>1,96$ ). This result is consistent with previous research on the relationship between organizational 
culture and manufacturing strategy on firm performance, and hence, it supported hypotheses $\mathrm{H} 3$ and $\mathrm{H} 4$. The last finding is that business process re-engineering has an impact on firm performance with $\beta=0.543$ and t-value $>1,96$. As a result, all hypotheses H1, H2, H3, H4, and $\mathrm{H} 5$ are supported as expected. Fig. 1 shows the complete result of analysis using PLS.

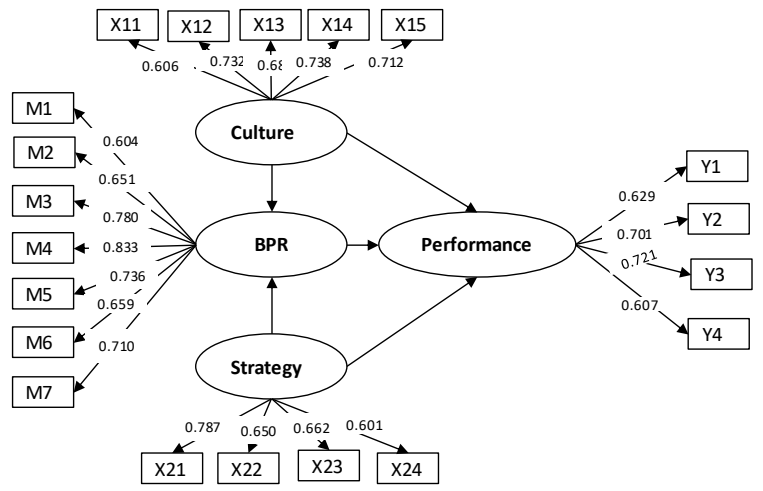

Fig. 1. Outer and inner research model.

One of the main aims of this study was to examine the mediating role of the business process re-engineering on the performance. Interestingly, business process re-engineering indeed mediates the impact of manufacturing strategy and organizational culture on the performance. This result consequently, revealed that the organizational culture and manufacturing strategy have the direct and indirect effect on the performance. The indirect effect of manufacturing strategy of 0.308 was obtained from the multiplication of path coefficient of manufacturing strategy to business process re-engineering (0.567) and of business process re-engineering to firm performance (0.543). Similarly, organizational culture also has an indirect effect on firm performance with the magnitude of 0.221 . This finding indicates that indirect effect of both independent variables on firm performance is $0.529(0.308+0.221)$, higher than its direct effect of $0.441(0.165+0.276)$. This means that the role of business process re-engineering in enhancing firm performance is highly significant. It doesn't mean, however, that we can ignore its direct effect but with the presence of business process re-engineering the total effect is doubled.

\section{Discussion}

The present study was designed to determine the effect of organizational culture and manufacturing strategy on firm performance through the mediating role of the business process re-engineering. The findings of this study indicate that the results are in agreement with the previous study. The most interesting finding was that business process re-engineering mediates the manufacturing strategy and organizational culture in influencing the firm performance. Interesting that, the highest direct impact on firm performance is contributed by business process re-engineering. This coincides with previous research arguing that business process re-engineering is the fundamental rethinking and radical redesign of business processes to obtain dramatic improvements in cost, quality, service, and speed. Business process re-engineering is a business process management tool which reviewed and redesigned and synchronized the process with the goal of the firm in such a way that minimum cost, quick delivery, and superior quality are achieved. Regardless the type of the business, process re-engineering should be implemented to succeed in the fiercely competitive environment. Its impact on performance confirms that business process re-engineering mediated the impact of organizational culture and manufacturing strategy on firm performance. The most interesting finding from the result is that indirect effect through business process is higher than that of the direct impact of organizational culture and manufacturing strategy on firm 
performance

Another finding from the result also indicates that manufacturing strategy influence firm performance more than does the organizational culture. However, it does not mean that the culture of the organization can be ignored. As literature suggested that organizational culture is a guiding value in the face of internal and external problems, so the employee of the organizations must understand those values and know how they should act or behave. The lower impact of culture on performance in this study may be explained as the region of the survey covering the same culture background which means, there is no significant difference in the working culture between the companies.

\section{Conclusion}

The primary aim of the present research was to examine the mediating role of the business process re-engineering in improving the performance. The study indicated that the results supported all proposed hypothesis on the relationship of manufacturing strategy, organizational culture, business process re-engineering and firm performance. This study has also shown that the business process re-engineering mediates the influence of manufacturing strategy and organizational culture on firm performance. Business process re-engineering also contributes a direct impact on firm performance. In another word, business process re-engineering has a very important role in improving performance. The major second finding shows that indirect effect of organizational culture and manufacturing strategy is higher than its direct effect. This means that the role of business process re-engineering is highly important. In another word, in the pursuit of better firm performance, manufacturing firm should firstly place an emphasis on defining the manufacturing strategy and then followed by the formulation and implementation of the relevant business process. Organizational culture gives a lower impact on performance. This may be explained as the respondent participating in the survey come from the similar culture background in the region of the East Java Island, Indonesia. Which means that working culture among the companies is not significantly different. However, it does not mean that organizational culture can be ignored but in contrary, the successful business process re-engineering should be supported by the organizational culture.

\section{References}

[1] Herzog, N., et al. (2009). Linkages between manufacturing strategy, benchmarking, performance measurement and business process re-engineering. Comput. Ind. Eng.

[2] Amoako-Gyampah, K., \& Acquaah, M. (2008). Manufacturing strategy, competitive strategy, and firm performance: An empirical study in a developing economy environment. Int. J. Prod.

[3] Narver, S. F., et al. (1994). Effect of market orientation on business profitability. J. Mark., 54, 20-35.

[4] Kaplan, R. S., \& Norton, D. P. (2005). The balanced scorecard: Measures that drive performance. Harvard Business Review, 83(7-8).

[5] Siagian, H., \& Widjaja, W. G. (2009). The influence of organizational culture and manufacturing strategy on firm performance through business process re-engineering.

[6] Kappos, A. (2000). Organizational culture and the achievement of ERP strategic advantages and BPR performance improvements.

[7] Herzog, N. V., et al. (2009). Linkages between manufacturing strategy, benchmarking, performance measurement and business process re-engineering. Comput. Ind. Eng., 37(3), 963-975.

[8] Hammer, M., \& Champy, J. (2001). Re-engineering the company - A manifesto for business revolution.

[9] Lindsay, A., et al. (2003). Business processes - attempts to find a definition. Inf. Softw. Technol.

[10] Goksoy, A., et al. (2012). Business process re-engineering: Strategic tool for managing organizational change an application in a multinational company. Int. J. Bus. 
[11] Yahya, K. K., et al. (2015). The perception of gen Y on organizational culture, religiosity and corruption in Malaysian public organizations.Procedia Econ. Financ., 31, 251-261.

[12] Schraeder, M., et al. (2005). Organizational culture in public sector organizations. Leadersh. Organ. Dev. J., 26(6), 492-502.

[13] Soedjono, S. (2005). Pengaruh budaya organisasi Terhadap kinerja organisasi dan kepuasan kerja karyawan pada terminal penumpang umum di surabaya. J. Manaj. dan Kewirausahaan.

[14] Acquaah, M., et al. (2008). Manufacturing strategy, competitive strategy and firm performance : An empirical study in a developing economy environment. Int. J. Prod. Econ., 111(2), 375-592.

[15] Leong, G. K., et al. (1990). Research in the process and content of manufacturing strategy. Omega, 18(2), 109-122.

[16] Garvin, D. D. A. (1993). Manufacturing strategic planning. Calif. Manage. Rev., 35, 85-106.

[17] Hudson, M., et al. (2001). Theory and practice in SME performance measurement systems. Int. J.

[18] Kotter, J. P. (2008). Organizational Culture, and Performance. Simon and Schuster.

[19] Roxa, E. (2012). Influence of organizational culture on company performance. 4(4), 420-425.

[20] Sun, H., \& Hong, C. (2002). The alignment between manufacturing and business strategies: Its influence on business performance. Technovation, 22(11), 699-705.

[21] Alas, R., et al. (2012). Management techniques in estonian organizations: Learning organization and business process re-engineering. Procedia - Soc. Behav. Sci., 62, 494-498.

[22] Yaghini, R. et al. (2012). Re-engineering the locomotive operation management process in the railways of Iran (RAI). Procedia - Soc. Behav. Sci., 43.

[23] Budiono, A., \& Loice, R. (2012). Business process re-engineering in motorcycle workshop X for business sustainability. Procedia Econ. Financ., 4, 33-43

[24] Goel, S., \& Chen, V. (2008). Can business process re-engineering lead to security vulnerabilities: Analyzing the reengineered process. Int. J. Prod. Econ.

[25] Chin, W. W., \& Todd, P. A. (1995). On the use, usefulness, and ease of use of structural equation modeling in MIS research: A note of caution. MIS Q., 19(2), 237-246.

[26] Chin, W. W. (1998). The partial least squares approach to structural equation modeling. Modern Methods for Business Research, 295-336.

[27] Moreno, A., \& Casiilas, J. (2008). Entrepreneurial orientation and growth of SMEs: A cusal model. Entrep. Theory Pract., 32(2), 507-528.

[28] Chin, W. W. (1998). The partial least square approach to structural equation modeling. Modern Methods for Business Research, 295-336.

[29] Fornell, C., \& Larcker, D. F. (1981). Evaluating structural equation models with unobservable variables and measurement error. J. Mark. Res. (JMR). Feb1981, 18(1), 39-50.

[30] Fornell, C., \& Larcker, D. F. (1981). Evaluation structural equation models with unobservable variables and measurement error. J. Mark. Res., 18(1), 39-50.

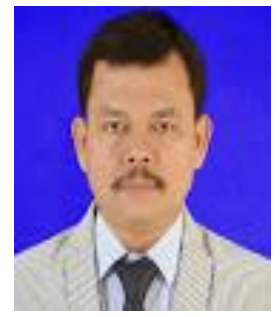

Hotlan Siagian is working as an assistant professor in Petra Christian University, Surabaya, Indonesia. He completed his doctoral of business management in 2014 from Padjadjaran University in Bandung, Indonesia. He got a strong research background and has published several papers on supply chain management and business process re-engineering. He is an Indonesian citizen and a fellow of Indonesian supply chain and logistic association. 
Hatane Semuel is working as a professor in Petra Christian University, Surabaya Indonesia. He completed his doctoral in 2001 from Brawijaya University in Malang, Indonesia. He has an extensive research background and has published many papers on marketing and social behavior. He is an Indonesian citizen and a fellow of marketing research association.

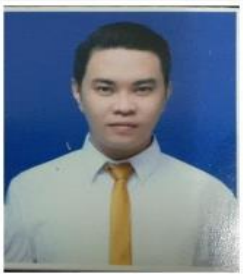

William Gondo Wijaya is a post graduate of master management in Petra Christian University. $\mathrm{He}$ is an Indonesian citizen and a business practitioner on supply chain management and a fellow of Supply chain association. 